\title{
Nutraceuticals, phytochemicals, and radical quenching ability of selected drought- tolerant advance lines of vegetable amaranth
}

\author{
Umakanta Sarker ${ }^{1 *}$ (iD and Shinya Oba
}

\begin{abstract}
Background: Vegetable amaranth is a source of natural phytopigments and functional components of the commercial food industry for sustainable health benefits across the globe. It is guessed that recently identified amaranth (drought-tolerant) genotypes may contain ample phytopigments and phytochemicals suitable to extract juice as drinks. Hence, phytopigments and phytochemicals content of amaranth were assessed in detail for suitability as drinks to feed the phytochemicals deficient community across the globe.

Results: The selected amaranth contained adequate carbohydrates, protein, moisture, and dietary fiber, phytopigments, minerals, phytochemicals including the ability to scavenge radicals. Nine flavonoids compounds were estimated in amaranth genotypes including six flavonols, one flavanol, one flavone, and one flavanone. It is the first effort in which we identified one flavonol such as myricetin, one flavanol, such as catechin, one flavone i. e., apigenin, and one flavanone, like naringenin in drought-tolerant vegetable amaranth. Across six flavonols, quercetin and rutin were the most noteworthy compounds followed by myricetin and isoquercetin. Across the accessions, AT7 and AT15 had abundant phytochemicals, and radical quenching ability including considerable proximate, nutraceuticals, and phytopigments in comparison to the accessions AT3 and AT11. AT15 demonstrated the maximum total flavonols including the highest rutin and hyperoside. AT7 showed high total flavonols including the highest quercetin, isoquercetin, myricetin, and kaempferol. The association of values revealed that studied phytopigments and phytochemicals of vegetable amaranth accessions demonstrated good radical quenching ability of 2,2-azino-bis (3-ethylbenzothiazoline-6-sulfonic acid) and 2,2- Diphenyl-1-picrylhydrazyl equivalent to Trolox.

Conclusions: These advance lines AT7 and AT15 had abundant nutraceuticals, phytopigments, and phytochemicals including radical quenching ability. These lines might significantly contribute to the promotion of health benefits and feeding the community across the globe deficit in nutraceuticals and antioxidants. Identified flavonoid compounds open the new route for pharmacological study.
\end{abstract}

Keywords: Vegetable amaranth, Drought-tolerant, Nutraceuticals, Pigments, Phenolics, Flavonols, Flavanol, Flavones, Flavanones, Antioxidant activity, HPLC-UV, LC-MS-ESI, DPPH, ABTS ${ }^{+}$

\footnotetext{
* Correspondence: umakanta@bsmrau.edu.bd

'Department of Genetics and Plant Breeding, Faculty of Agriculture,

Bangabandhu Sheikh Mujibur Rahman Agricultural University, Gazipur-1706, Bangladesh

Full list of author information is available at the end of the article
}

C C The Author(s). 2020 Open Access This article is licensed under a Creative Commons Attribution 4.0 International License, which permits use, sharing, adaptation, distribution and reproduction in any medium or format, as long as you give appropriate credit to the original author(s) and the source, provide a link to the Creative Commons licence, and indicate if changes were made. The images or other third party material in this article are included in the article's Creative Commons licence, unless indicated otherwise in a credit line to the material. If material is not included in the article's Creative Commons licence and your intended use is not permitted by statutory regulation or exceeds the permitted use, you will need to obtain permission directly from the copyright holder. To view a copy of this licence, visit http://creativecommons.org/licenses/by/4.0/. The Creative Commons Public Domain Dedication waiver (http://creativecommons.org/publicdomain/zero/1.0/) applies to the data made available in this article, unless otherwise stated in a credit line to the data. 


\section{Background}

Vegetable amaranths are low-cost vegetables containing abundant nutraceuticals, minerals [1-7], phytopigments $[8,9]$, phytochemicals [10] including the important capacity to quench radicals and predominantly influenced the commercial food industry [11-13]. It has excessive phenotypic divergence in Bangladesh and Asia [14] and diversified culinary usage.

Recently, natural antioxidants, especially from vegetables attain the interest of researchers and consumers. Phytopigments containing betacyanins, betaxanthins, chlorophylls, carotenoids, and phytochemicals including vitamin $\mathrm{C}, \beta$-carotene, flavonoids, and phenolics are available natural antioxidants in vegetable amaranth $[11,12]$. These bioactive compounds protect numerous diseases including atherosclerosis, cardiovascular diseases, emphysema, cancer, retinopathy, cataracts, arthritis, and neurodegenerative diseases [15-17].

Leafy vegetables are the principal origin of natural antioxidants. Generally, vegetables (leafy) are so susceptible to abiotic stress like drought. The exploitation of drought-tolerant genetic resources at various stages of growth is foremost for semiarid regions [18]. Drought stress limits the leafy vegetables production in the drought-prone area though restriction of growth of leafy vegetables because of oxidative stress by inhibiting the cell elongation and expansion, reducing turgor pressure, altering the energy from growth to synthesis of secondary metabolites, reducing the water uptake, decreasing the tissue water contents, reducing the photoassimilation and metabolites for cell division, generating the excessive free oxygen radicals [19]. The major sign of drought is osmotic stress that disrupts the ion distribution and homeostasis in the cell [20]. Hence, people of drought-prone areas are deprived of natural antioxidants through the production and consumption of leafy vegetables. However, vegetable amaranth is tolerant of drought [19, 21-23] and salinity [24-27]. Furthermore, previous studies of amaranth have displayed that drought stress remarkably augmented the ash, energy, protein, dietary fiber, $\mathrm{Cu}, \mathrm{Ca}, \mathrm{Mn}, \mathrm{K}, \mathrm{S}, \mathrm{Na}, \mathrm{Mg}, \mathrm{B}, \mathrm{Mo}$ content, TFC, TPC, vitamin $\mathrm{C}$, total carotenoids, TAC (DPPH), beta-carotene, TAC (ABTS), flavonoids, and phenolic acids [21, 22]. A certain level of drought stress (eustress) remarkably augmented these nutraceuticals, phytopigments, and phytochemicals without compromising the loss of foliage yield $[21,22]$. In literature, researchers reported that drought stress augmented the beta-carotene content in Brassica species [28] and herbs [29], vitamin $C$ in tomato [30], flavonoids and polyphenols in buckwheat [31], antioxidant capacity, flavonoids, and polyphenols composition in Achillea species [32] antioxidant enzymes activity in walnut leaf [33], seedling
[34], sugars and proline in radicle and plumule [35]; shoots and roots [36] of tolerant walnut.

Free radicals-induced injury predominantly depends on its equilibrium between formation and quenching through the antioxidant detoxification system [37]. Secondary metabolites synthesis like phytochemicals, phenolics, and flavonoids in stress induced-plants has excellent protection systems against free radicals to adjust the damage of oxidative stress [38]. These metabolites can quench free radicals in plants, as well as intake in the diet also have a significant role to cure many human oxidative damage and aging-related diseases [39].

In the previous studies, this research group screened vegetable amaranth germplasms based on agronomic performance, TAC, and yields compared with high yielding and antioxidant enrich existing popular cultivars and identified several high antioxidants enrich and high yield potential genotypes $[1-5,7,40]$. These identified genotypes were again screened against drought-stress to recognize the drought-tolerant accessions (Data not published). However, the nutraceuticals, phytopigments, and phytochemicals of antioxidants enrich droughttolerant genotypes not assessed yet. It is guessed that the selected antioxidants enrich genotypes (tolerant to drought stress) may contain adequate nutraceuticals, phytopigments, and phytochemicals suitable to extract juice as drinks. Hence, the study was aimed to assess the chance of utilizing high yielding and antioxidant enrich amaranth as a source of natural nutraceuticals, phytopigments, and functional components for the industry of foods. Therefore, nutraceuticals, phytopigments, and phytochemicals content of amaranth were explored in detail for suitability as drinks to feed the phytochemicals deficient community across the globe.

\section{Methods \\ Materials}

Department of GPB of BSMRAU provided the seeds of four drought-tolerant advance genotypes. The detailed information of the genotypes is given in Table 1.

\section{Experimental site, design, and layout}

The evaluation was done in three replicates using a completely randomized block design (RCBD) at BSMRAU from 1st to 31st March 2015 (categorized as a subtropical zone, AEZ-28, $24^{\circ} 23^{\prime}$ north latitude, $90^{\circ} 08^{\prime}$ east longitude). The type of soil of the growing place is silty clay with monthly mean temperatures during the cropping period (maximum $34.00^{\circ} \mathrm{C}$, minimum $19.00{ }^{\circ} \mathrm{C}$, and average $26.50{ }^{\circ} \mathrm{C}$ ) and average relative humidity $54 \%$. Each genotype was grown in one $\mathrm{m}^{2}$ plot on 1 st March maintaining the distance of the rows of $20 \mathrm{~cm}$ and plants distance $5 \mathrm{~cm}$. 
Table 1 The detailed information of the genotypes utilized in the study

\begin{tabular}{|c|c|c|c|c|}
\hline Genotype & AT3 & AT7 & AT11 & AT15 \\
\hline English name & Vegetable amaranth & Vegetable amaranth & Vegetable amaranth & Vegetable amaranth \\
\hline Scientific name & Amaranthus tricolor & Amaranthus tricolor & Amaranthus tricolor & Amaranthus tricolor \\
\hline Category & Leafy vegetables & Leafy vegetables & Leafy vegetables & Leafy vegetables \\
\hline Edible parts & Baby stems and leaves & Baby stems and leaves & Baby stems and leaves & Baby stems and leaves \\
\hline Usage & Salad or boiled & Salad or boiled & Salad or boiled & Salad or boiled \\
\hline Edible stage & 30 days old & 30 days old & 30 days old & 30 days old \\
\hline Characteristics & Red stems and leaves & Red stems and leaves & Red stems and leaves & Red stems and leaves \\
\hline Source & Collection & Collection & Collection & Collection \\
\hline Distinctive remark & Drought tolerant & Drought tolerant & Drought tolerant & Drought tolerant \\
\hline
\end{tabular}

\section{Intercultural practices}

The compost (10 ton/ha) was amended during land preparation. TSP, Urea, MP, and Gypsum were utilized @ 100, 200, 150, and $30 \mathrm{~kg} / \mathrm{ha}$, respectively [40]. Intercultural operations, such as thinning, irrigation, and weeding were provided as required. The edible leaves of 10 selected plants (thirty days old) were randomly sampled.

\section{Estimation of proximate composition}

Crude fat, ash, fiber, moisture, protein contents, and energy (gross) were measured by applying the AOAC method [41]. Crude protein was assessed by the MicroKjeldahl method. Finally, nitrogen was multiplied by 6.25 to measure crude protein (AOAC method 976.05). The protein, moisture, ash, and crude fat (\%) was deducted from 100 for calculating carbohydrate (g 100 $\left.\mathrm{g}^{-1} \mathrm{FW}\right)[21,22]$.

\section{Mineral composition estimation}

The leaves (fresh) were dried in an oven at $70^{\circ} \mathrm{C}$ for 24 h. Calcium, potassium, magnesium, iron, manganese, copper, and zinc were determined from leaf powder following the digestion method of nitric-perchloric acid $[21,22]$. The digestion was performed with carborundum beads adding $40 \mathrm{ml} \mathrm{HClO}_{4}(70 \%), 400 \mathrm{ml} \mathrm{HNO}_{3}$ (65\%), $10 \mathrm{ml} \mathrm{H}_{2} \mathrm{SO}_{4}$ (96\%) and $0.5 \mathrm{~g}$ dried leaf sample. After digestion, the method of ascorbic acid was followed to measure $\mathrm{P}$ through dilution of the solution appropriately in triplicate. Ascorbic acid and antimony were poured into the yellow-colored complex solution for converting it to a blue-colored phosphomolybdenum complex [42]. The optical density was estimated by atomic absorption spectrophotometry (AAS) (Hitachi, Tokyo, Japan) at wavelengths of $285.2 \mathrm{~nm}$ (magnesium), $248.3 \mathrm{~nm}$ (iron), $766.5 \mathrm{~nm}$ (potassium), $324.8 \mathrm{~nm}$ (copper), $422.7 \mathrm{~nm}$ (calcium), $213.9 \mathrm{~nm}$ (zinc), $279.5 \mathrm{~nm}$ (manganese).

\section{Determination of chlorophylls and carotenoids}

Chlorophyll $a b$, chlorophyll $b$, carotenoids, and chlorophyll $a$ were calculated by extracting the leaves in acetone $(80 \%)$ [22, 43]. The optical density was taken using a spectrophotometer (Hitachi, Japan) at 646, 470, $663 \mathrm{~nm}$ for chlorophyll $b$, carotenoids, and chlorophyll $a$, respectively.

The formulae [44] were given below:

$$
\begin{aligned}
& \text { Chlorophyll } a(\mu \mathrm{g} / \mathrm{mL})=\mathrm{C}_{a}=12.21 \mathrm{~A}_{663}-2.81 \mathrm{~A}_{646} \\
& \text { Chlorophyll } b(\mu \mathrm{g} / \mathrm{mL})=\mathrm{C}_{b}=20.13 \mathrm{~A}_{646}-5.03 \mathrm{~A}_{663} \\
& \text { Carotenoids }(\mu \mathrm{g} / \mathrm{mL})=\left(1000 \mathrm{~A}_{470}-3.27 \mathrm{C}_{a}-104 \mathrm{C}_{b}\right) / 229
\end{aligned}
$$

Where: $A_{646}=$ absorbance at a wavelength of $646 \mathrm{~nm}$; $\mathrm{A}_{663}=$ absorbance at a wavelength of $663 \mathrm{~nm} ; \mathrm{A}_{470}=\mathrm{ab}-$ sorbance at a wavelength of $470 \mathrm{~nm}$.

Finally, chlorophylls were calculated as micrograms per gram and carotenoids milligrams per $100 \mathrm{~g}$ of fresh weight, respectively.

\section{Betacyanins and betaxanthins content measurement}

The leaves were extracted in methanol (80\%, with 50 $\mathrm{mM}$ ascorbate) to estimate betacyanins and betaxanthins [22, 45]. The optical density was taken using a spectrophotometer (Hitachi, Japan) at 540 and $475 \mathrm{~nm}$ for betacyanins and betaxanthins, respectively. The data were calculated as nanograms betanin equivalent per gram of fresh weight for betacyanins and nanograms indicaxanthin equivalent per gram of fresh weight for betaxanthins [46].

\section{Estimation of beta-carotene}

Ten $\mathrm{ml}$ acetone $(80 \%)$ was mixed with $0.5 \mathrm{~g}$ leaves (fresh) and ground thoroughly. After centrifugation of the extract for 3-4 min at $10,000 \times$ g, the supernatant was removed and the volumetric flask was marked at the final volume of $20 \mathrm{ml}[22,47]$. The optical density was 
measured with a spectrophotometer (Hitachi, Japan) at 480 and $510 \mathrm{~nm}$. Finally, the results were quantified as mg beta-carotene per $100 \mathrm{~g}$ FW.

Beta-carotene $=7.6$ (Abs. at 480) - 1.49 (Abs. at 510) $\times$ Final volume $/(1000 \times$ fresh weight of leaf $)$ [48]

\section{Estimation of ascorbic acid}

By pre-incubating and reducing the DHA of samples using Dithiothreitol, the ascorbic acid was determined. AsA reduced $\mathrm{Fe}^{3+}$ to $\mathrm{Fe}^{2+}$ ion. $\mathrm{Fe}^{2+}$ form complexes by binding with 2, 2-dipyridyl. The optical density of complexes was read by a spectrophotometer at $525 \mathrm{~nm}$. The results were expressed as $\mathrm{mg} 100 \mathrm{~g}^{-1} \mathrm{FW}[22,49]$.

\section{Samples extraction for TF, TP, and TAC}

Leaves were air-dried in a shade. The extraction was performed in a capped test tube by mixing forty $\mathrm{ml}$ of $90 \%$ aqueous methanol with $1 \mathrm{~g}$ of fresh leaves (for TF) and dried leaf powder (for TF and TAC) of each genotype. After shaking the test tubes on a water bath shaker for $1 \mathrm{~h}$, the mixture was centrifuged at $10,000 \times \mathrm{g}$ for 15 min and filtered through a $0.45 \mu \mathrm{m}$ filter. The TF, TAC, and TP were measured from this extract.

\section{Total polyphenols (TP) estimation}

The determination of TP was performed following the previous method [22] using the reagent of FolinCiocalteau. The optical density was measured with a spectrophotometer (Hitachi, Japan) at $760 \mathrm{~nm}$. The data were expressed as GAE $\mu \mathrm{g} \mathrm{g}^{-1} \mathrm{FW}$.

\section{Estimation of total flavonoids (TF)}

The TF estimation was performed following the protocol of Sarker \& Oba [22] using the AlCl3 method. The optical density was measured with a spectrophotometer (Hitachi, Japan) at $415 \mathrm{~nm}$. The data were expressed as RE $\mu g g^{-1}$ DW.

\section{Radical quenching capacity assay}

The determination of radical quenching capacity (RQA) was performed following the DPPH radical scavenging assay $[22,50]$ and the ABTS method [22, 51]. The optical density was measured using a spectrophotometer (Hitachi, Japan) at 517 and $734 \mathrm{~nm}$ for DPPH and ABTS, respectively. The RQA (ABTS and DPPH) was determined following the equation:

RQA $(\%)=\left(\mathrm{OD}_{\mathrm{b}}-\mathrm{ODs} / \mathrm{OD}_{\mathrm{b}}\right) \times 100$.

Where, $\mathrm{RQA}=$ radical quenching capacity, $\mathrm{OD}_{\mathrm{b}}=\mathrm{op}-$ tical density (blank) [as a replacement of extract, one hundred fifty and ten $\mu \mathrm{l}$ methyl alcohol for ABTS and $\mathrm{DPPH}$, respectively], and ODs $=$ The optical density of samples tested. The data were measured as $\mu \mathrm{g}$ TEAC $\mathrm{g}^{-1}$ DW.

\section{Flavonols, flavanols, flavones, and flavanones analysis through HPLC}

The leaf samples were extracted following the protocol described by Sarker and Oba [47, 49].

Flavonols, flavanols, flavones, and flavanones in the leaf sample were estimated using a Shimadzu SCL10Avp (Kyoto, Japan) HPLC equipped with a detector, binary pump, and degasser following the method of Sarker and oba $[47,49]$. Flavonols, flavanols, flavones, and flavanones were separated using a column (STR ODS-II, $150 \times 4.6 \mathrm{~mm}$ I.D., Kyoto, Japan). Acetic acid (6\% v/v) in water and acetonitrile were pumped @ $1 \mathrm{ml} / \mathrm{min}$ for 70 min by the binary mobile phase as solvent $\mathrm{A}$ and solvent $B$, respectively. The injection volume and temperature of the column were maintained at $35^{\circ} \mathrm{C}$ and $10 \mu \mathrm{l}$, respectively. Flavonols, flavanols, flavones, and flavanones were continuously monitored by setting the detector at 280, 370 , and $360 \mathrm{~nm}$. The compound's identification was performed by comparing the retention time and UV-Vis spectra with its individual standards. The flavonols, flavones, flavanols, and flavanones were quantified using calibration curves of respective standards and confirmed through evaluating mass spectrometry. The identified compounds were determined as $\mathrm{mg} \mathrm{kg}^{-1} \mathrm{FW}$.

\section{Statistical analysis}

The sample data were averaged replication-wise to obtain the replication mean. Statistix 8 software was used to analyze the data for analysis of variance (ANOVA) $[52,53]$. Duncan Multiple Range Test at a $1 \%$ level of probability was used to compare the means. The results were reported as the mean $\pm \mathrm{SD}$.

\section{Results}

The ANOVA revealed that amaranth demonstrated huge variations across the traits studied.

\section{Composition of proximate}

The composition of the proximate of selected amaranth is given in Fig. 1. The moisture of selected accessions

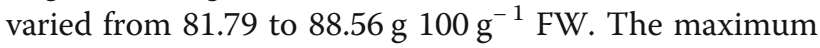
content of moisture was noted in the advance line AT11

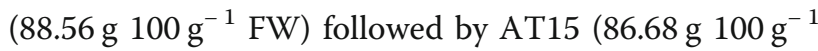
FW) and AT3 (86.57 g $\left.100 \mathrm{~g}^{-1} \mathrm{FW}\right)$. On the contrary, the minimum moisture content was recorded in AT7 (81.79 g $\left.100 \mathrm{~g}^{-1} \mathrm{FW}\right)$. Amaranth demonstrated considerable protein content that significantly varied regarding accessions albeit variability was not prominent (5.05 to

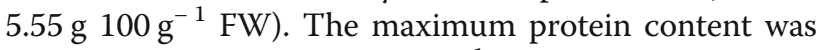

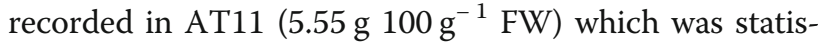
tically similar to AT3 and AT7. Conversely, the mini-

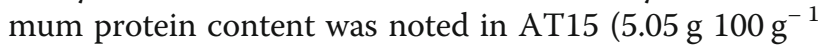
FW). Higher protein content was obtained from AT11, 


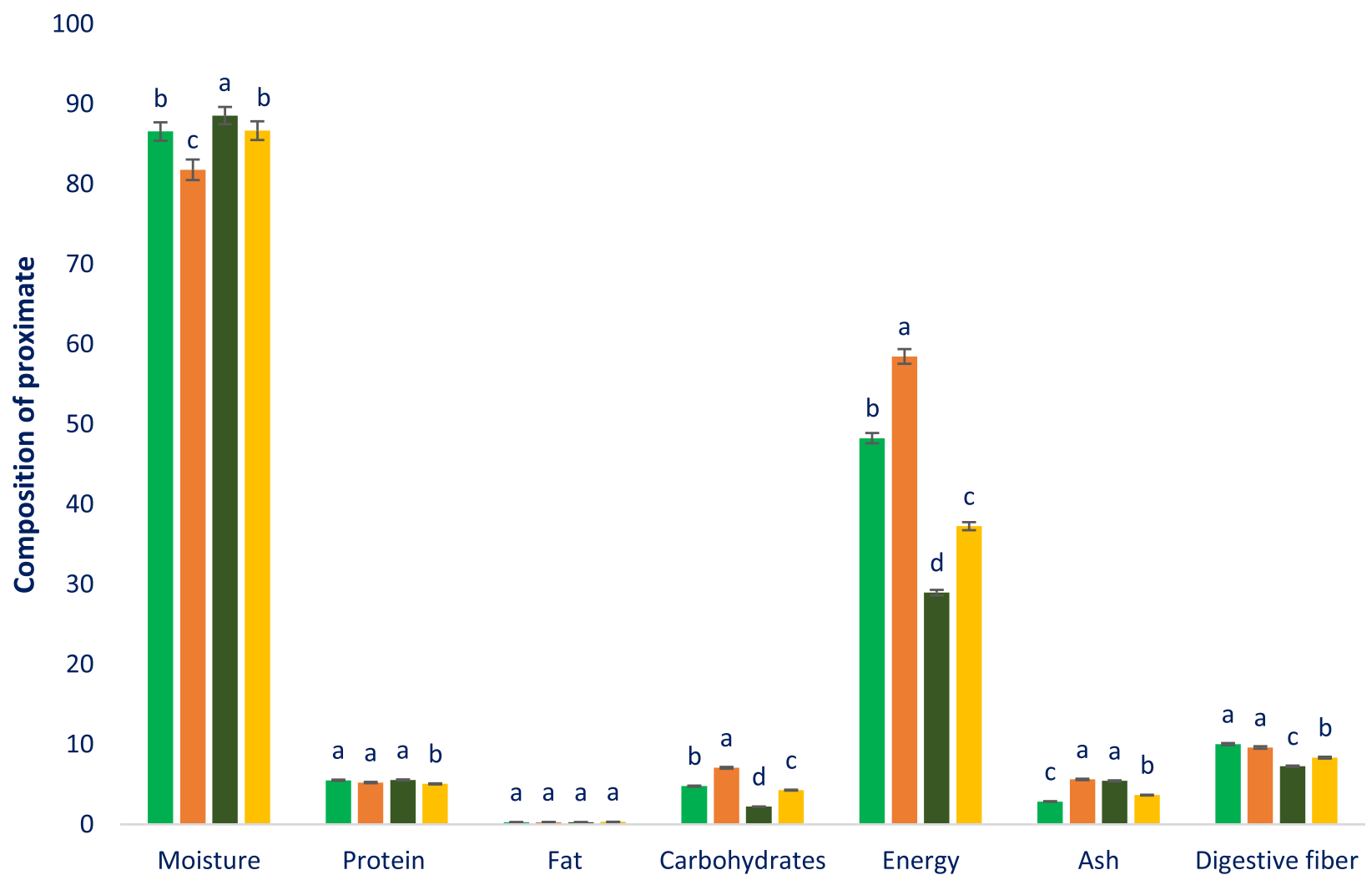

Fig. 1 Composition of proximate (per $100 \mathrm{~g}^{-1} \mathrm{FW}$ ) (energy $\mathrm{kcal}$ ) in four selected drought-tolerant vegetable amaranth, different letters are differed significantly by Duncan Multiple Range Test $(P<0.01),(n=6)$

AT3, and AT7. In this investigation, amaranth demonstrated low-fat content.

The selected lines demonstrated significant variations in carbohydrates content regarding accessions (2.21 to

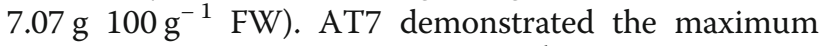

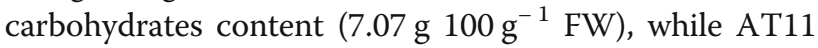
had the minimum carbohydrates content $\left(2.21{\mathrm{~g} 100 \mathrm{~g}^{-1}}^{-1}\right.$ FW). The selected lines were predominantly varied with

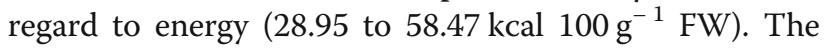
accession AT7 demonstrated the maximum energy $\left(58.47 \mathrm{kcal} 100 \mathrm{~g}^{-1} \mathrm{FW}\right)$. Alternatively, the accession AT11 exerted the minimum energy $\left(28.95 \mathrm{kcal} 100 \mathrm{~g}^{-1}\right.$ FW). AT7 and AT11 demonstrated the maximum ash

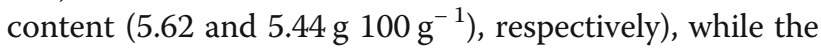
minimum ash content was noted in AT3 $(2.86 \mathrm{~g} 100$ $\mathrm{g}^{-1}$ ). Digestible fiber predominantly varied regarding

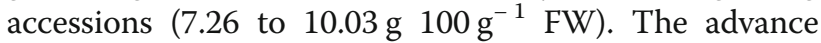
accession AT3 demonstrated the maximum digestible fiber content $\left(10.03 \mathrm{~g} 100 \mathrm{~g}^{-1} \mathrm{FW}\right)$ followed by AT7. Conversely, AT11 had the minimum digestible fiber content (7.26 g $\left.100 \mathrm{~g}^{-1} \mathrm{FW}\right)$.

\section{Mineral elements}

Mineral elements of selected amaranth are put in Fig. 2. The lines demonstrated significant variability in potassium content regarding accessions. The maximum content of potassium was noted in AT15 $\left(6.68 \mathrm{mg} \mathrm{g}^{-1}\right)$ followed by AT3, AT7, and AT11 including mean content of potassium of $5.81 \mathrm{mg} \mathrm{g}^{-1}$. The maximum content of calcium was noticed in AT3 $\left(2.48 \mathrm{mg} \mathrm{g}^{-1}\right)$ followed by AT11 and AT15. In contrast, the minimum content of calcium was noticed in AT7 $\left(1.87 \mathrm{mg} \mathrm{g}^{-1}\right)$. In this investigation, the selected amaranth demonstrated significant variability in magnesium content regarding accessions (3.26 to $\left.3.62 \mathrm{mg} \mathrm{g}^{-1} \mathrm{FW}\right)$. AT15 demonstrated the maximum content of magnesium $\left(3.62 \mathrm{mg} \mathrm{g}^{-1} \mathrm{FW}\right)$. Conversely, AT7 demonstrated the minimum content of magnesium $\left(3.26 \mathrm{mg} \mathrm{g}^{-1} \mathrm{FW}\right)$ that had statistical similarity to AT3, AT11.

The iron content demonstrated significant variations regarding accessions (10.96 to $17.26 \mu \mathrm{g} \mathrm{g}^{-1}$ ). The maximum iron content was obtained from AT15 (17.26 $\mu \mathrm{g}$ $\left.\mathrm{g}^{-1} \mathrm{FW}\right)$, while the minimum iron content was noted in 


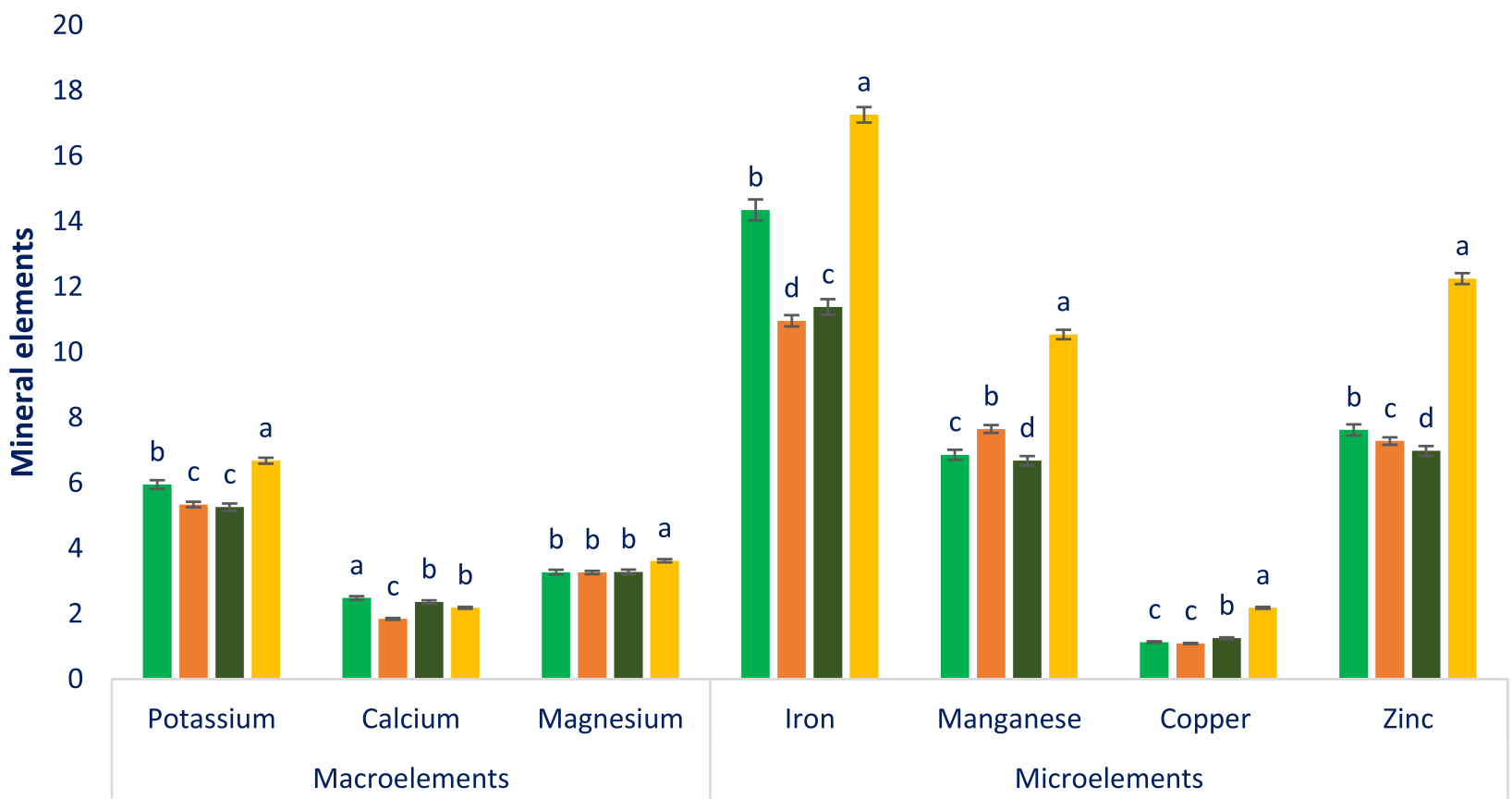

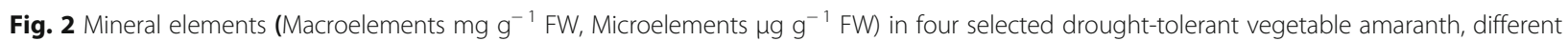
letters are differed significantly by Duncan Multiple Range Test $(P<0.01),(n=6)$

AT7 $\left(10.96 \mu \mathrm{g} \mathrm{g}^{-1} \mathrm{FW}\right)$. It revealed from our study that significant variability in manganese content regarding accessions was noticed in amaranth $\left(6.68 \mu \mathrm{g} \mathrm{g}^{-1} \mathrm{FW}\right.$ and \left.$10.54{\mu \mathrm{gg}^{-1}} \mathrm{FW}\right)$. Manganese content was the maximum in AT15 $\left(10.54 \mu \mathrm{gg}^{-1} \mathrm{FW}\right)$, while the minimum manganese content was recorded in AT11 and AT3

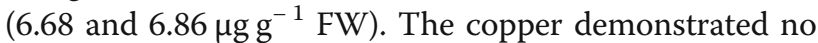
notable and significant variability in amaranth genotypes

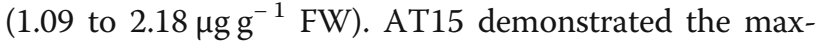
imum copper content $\left(2.18 \mu \mathrm{gg}^{-1} \mathrm{FW}\right)$, while AT7 exerted the minimum copper content $\left(1.09 \mu \mathrm{gg}^{-1} \mathrm{FW}\right)$. The zinc of amaranth differed significantly and markedly (6.98 $\mu \mathrm{g} \mathrm{g}^{-1} \mathrm{FW}$ in AT3 to $12.25 \mu \mathrm{g} \mathrm{g}^{-1} \mathrm{FW}$ in AT15).

\section{Phytopigment contents}

Phytopigments of the selected amaranth are put in Fig. 3. The significant variability in chlorophyll $a$ was noted regarding the selected amaranth (305.85 to $634.75 \mu \mathrm{g} \mathrm{g}^{-1}$ FW). AT7 demonstrated the maximum chlorophyll $a$ $\left(634.75 \mu \mathrm{g} \mathrm{g}^{-1} \mathrm{FW}\right)$ followed by AT11 and AT15. Alternatively, the minimum chlorophyll $a\left(305.85 \mu \mathrm{g} \mathrm{g}^{-1} \mathrm{FW}\right)$ was noted in AT3. Conversely, the selected amaranth demonstrated minimum differences in chlorophyll $b$

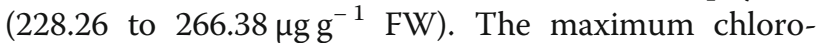
phyll $b$ was recorded in AT7 $\left(266.38 \mu \mathrm{gg}^{-1}\right.$ FW) followed by AT11. In contrast, AT6 demonstrated the minimum chlorophyll $b \quad\left(228.26 \mu \mathrm{gg}^{-1} \quad \mathrm{FW}\right)$. The significant variability in chlorophyll $a b$ was recorded in amaranth genotypes (534.11 to $901.13 \mu \mathrm{g} \mathrm{g}^{-1} \mathrm{FW}$ ). The advance line AT7 demonstrated the maximum chlorophyll $a b\left(901.13{\mu \mathrm{gg}^{-1}} \mathrm{FW}\right)$ followed by AT11 and AT15, while AT3 demonstrated the minimum chlorophyll $a b$ (534.11 $\left.\mu \mathrm{g} \mathrm{g}^{-1} \mathrm{FW}\right)$.

The selected amaranth demonstrated significant variability in betacyanin content regarding accessions (407.97 to $537.26 \mathrm{ng} \mathrm{g}^{-1} \mathrm{FW}$ ). AT3 demonstrated the maximum content of betacyanins (537.26 $\mathrm{ng} \mathrm{g}^{-1} \mathrm{FW}$ ) followed by AT11 and AT15. In contrast, AT7 demonstrated the minimum content of betacyanins $(407.97 \mathrm{ng}$ $\left.\mathrm{g}^{-1} \mathrm{FW}\right)$. The selected lines demonstrated significant variations in betaxanthins regarding accessions (428.45 to $\left.588.75 \mathrm{ng} \mathrm{g}^{-1} \mathrm{FW}\right)$. AT3 demonstrated the maximum content of betaxanthins (588.75 $\left.\mathrm{ng} \mathrm{g}^{-1} \mathrm{FW}\right)$ followed by AT11 and AT15. Conversely, the minimum content of betaxanthins was noted in AT7 (428.45 $\left.\mathrm{ng} \mathrm{g}^{-1} \mathrm{FW}\right)$. The selected amaranth demonstrated significant variations in betalains content regarding accessions (836.42 to $\left.1126.01 \mathrm{ng} \mathrm{g}^{-1} \mathrm{FW}\right)$. The AT3 demonstrated the maximum betalains (1126.01 $\left.\mathrm{ng} \mathrm{g}^{-1} \mathrm{FW}\right)$ followed by AT11 and AT15. While the AT7 demonstrated minimum betalains (836.42 $\left.\mathrm{ng} \mathrm{g}^{-1} \mathrm{FW}\right)$. Likewise, betalains, carotenoids showed significant variability in amaranth genotypes

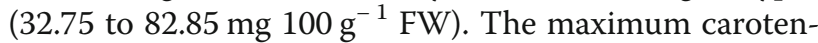
oids were recorded in AT15 (82.85 mg $100 \mathrm{~g}^{-1} \mathrm{FW}$ ). 


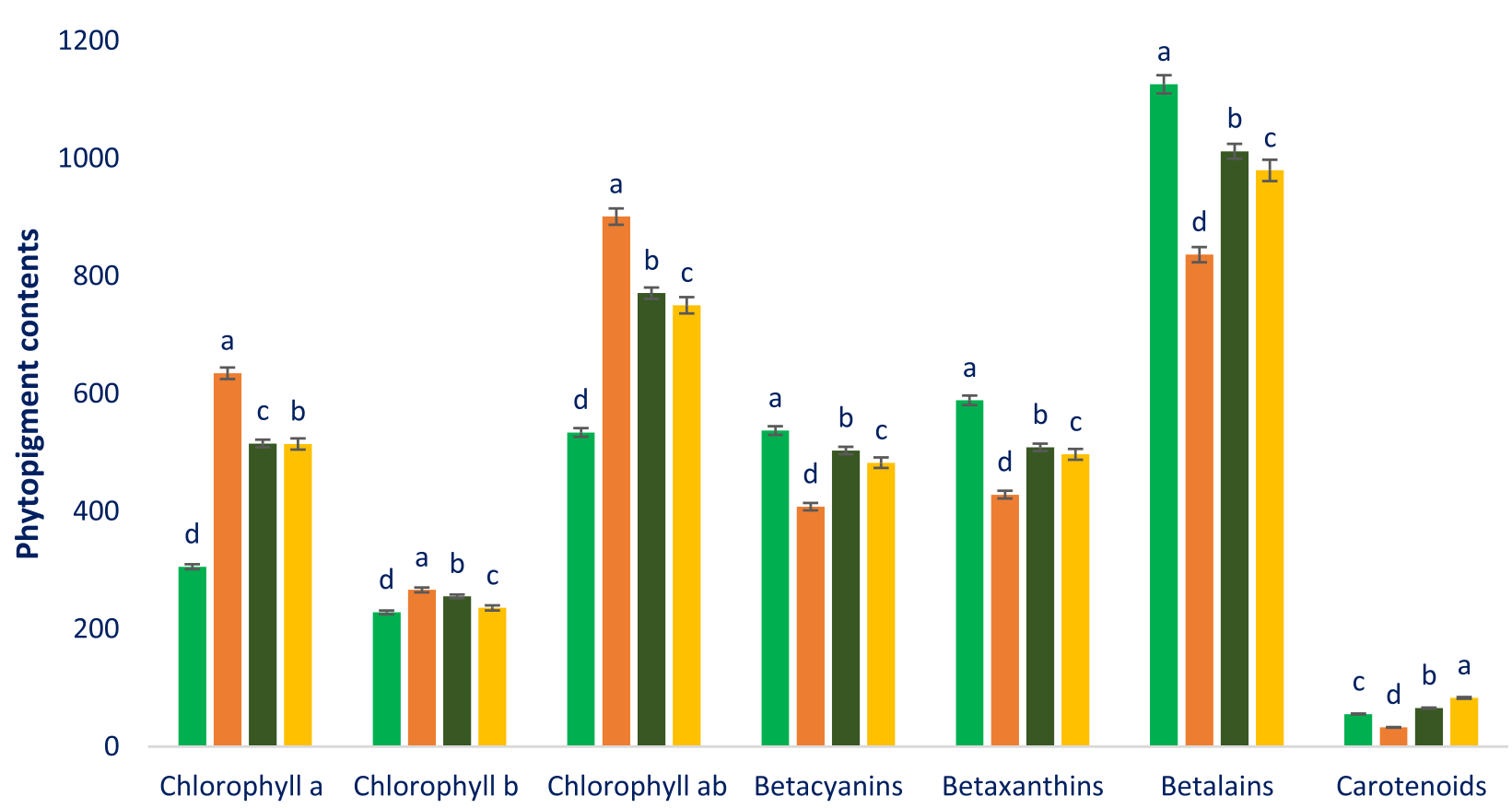

Fig. 3 Phytopigments contents in four selected drought-tolerant vegetable amaranth, betacyanins ( $\mathrm{ng} \mathrm{g}^{-1} \mathrm{FW}$ ), chlorophyll $a$ ( $\mu \mathrm{g} \mathrm{g} \mathrm{g}^{-1} \mathrm{FW}$ ), betaxanthins ( $\mathrm{ng} \mathrm{g}^{-1} \mathrm{FW}$ ), chlorophyll $b\left(\mu \mathrm{g} \mathrm{g}^{-1} \mathrm{FW}\right)$, betalains (ng g ${ }^{-1} \mathrm{FW}$ ), chlorophyll $a b\left(\mu \mathrm{g} \mathrm{g}^{-1} \mathrm{FW}\right)$, carotenoids (mg $\left.100 \mathrm{~g}^{-1} \mathrm{FW}\right)$, different letters in the bar are differed significantly by Duncan Multiple Range Test $((P<0.01),(n=6)$

Whereas, AT7 demonstrated the minimum carotenoids

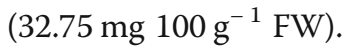

\section{Phytochemicals contents and radical quenching ability}

$\beta$-Carotene, ascorbic acid, total polyphenols (TP), total flavonoids (TF), and radical quenching capacity of amaranth are put in Fig. 4. The significant variability was recorded in the $\beta$-carotene of the selected amaranth

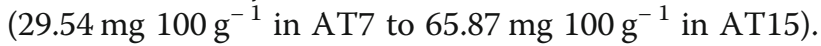
The high content of $\beta$-carotene.

was noticed in AT11. The lines demonstrated significant variability in ascorbic acid (18.54 to $105.78 \mathrm{mg} 100$ $\left.\mathrm{g}^{-1} \mathrm{FW}\right)$. Ascorbic acid was the maximum in AT11

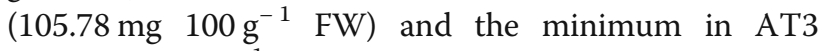
(18.54 mg $\left.100 \mathrm{~g}^{-1} \mathrm{FW}\right)$. Marked and significant variability was recorded in gallic acid equivalent (GE) TP in the accessions $\left(28.65{\mu \mathrm{gg}^{-1}}^{-10} 38.23 \mu \mathrm{gg}^{-1} \mathrm{FW}\right)$. AT15 demonstrated the maximum TP content $\left(38.23 \mu \mathrm{gg}^{-1}\right)$ followed by AT7. While AT3 demonstrated the minimum TP $\left(28.65 \mathrm{gg}^{-1}\right)$ that had statistical similarity with AT11. The selected amaranth demonstrated rutin equivalent (RE) TF with significant variability regarding accessions $\left(146.58{\mu \mathrm{gg}^{-1}}^{-1}\right.$ to $\left.166.81 \mu \mathrm{g} \mathrm{g}^{-1} \mathrm{DW}\right)$. AT15

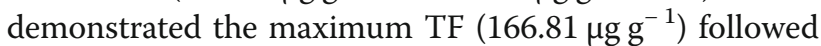
by AT7 and AT11, whereas AT3 had the minimum TF $\left(146.58 \mu \mathrm{gg}^{-1}\right)$. The selected amaranth demonstrated high DPPH and $\mathrm{ABTS}^{+}$radical quenching ability. AT15 demonstrated the maximum Trolox equivalent (TE) DPPH and $\mathrm{ABTS}^{+}$radical quenching ability (40.75, $\left.76.98 \mu \mathrm{g} \mathrm{g}^{-1}\right)$ followed by AT7 $\left(38.25,72.96 \mu \mathrm{g} \mathrm{g}^{-1}\right)$. Alternatively, the minimum $\mathrm{DPPH}$ and $\mathrm{ABTS}^{+}$radical quenching ability were recorded in AT3 $(32.48,58.75 \mu \mathrm{g}$ $\left.\mathrm{g}^{-1}\right)$ followed by AT11 $\left(35.23,64.23 \mu \mathrm{g} \mathrm{g}^{-1}\right)$.

\section{Flavonols, flavanols, flavones, and flavanones}

The data of Table 2 represents the identified compounds, retention time, the molecular ion, main fragment ions in $\mathrm{MS}^{2}$, and $\lambda \max$. The separated flavonols, flavones, flavanols, and flavanones compounds of four accessions of amaranth (AT3, AT7, AT11, and AT15) were compared with respective peaks and standard masses of these flavonols, flavones, flavanols, and flavanones. Nine flavonoids were detected in amaranth genotypes together with six flavonols, like kaempferol, rutin, hyperoside, myricetin, isoquercetin, and quercetin, one flavanol, like catechin, one flavone like apigenin, and one flavanone, such as naringenin. It is the first effort in which we identified one flavonols such as myricetin, one flavanol, such as catechin, one flavone i. e.,

apigenin, and one flavanone, like naringenin in amaranth genotypes. Figure 5 represents the identified flavonols compounds and Fig. 6 demonstrates the identified 


\section{$\square$ AT3 $\square$ AT7 $\square$ AT11 $\square$ AT15}

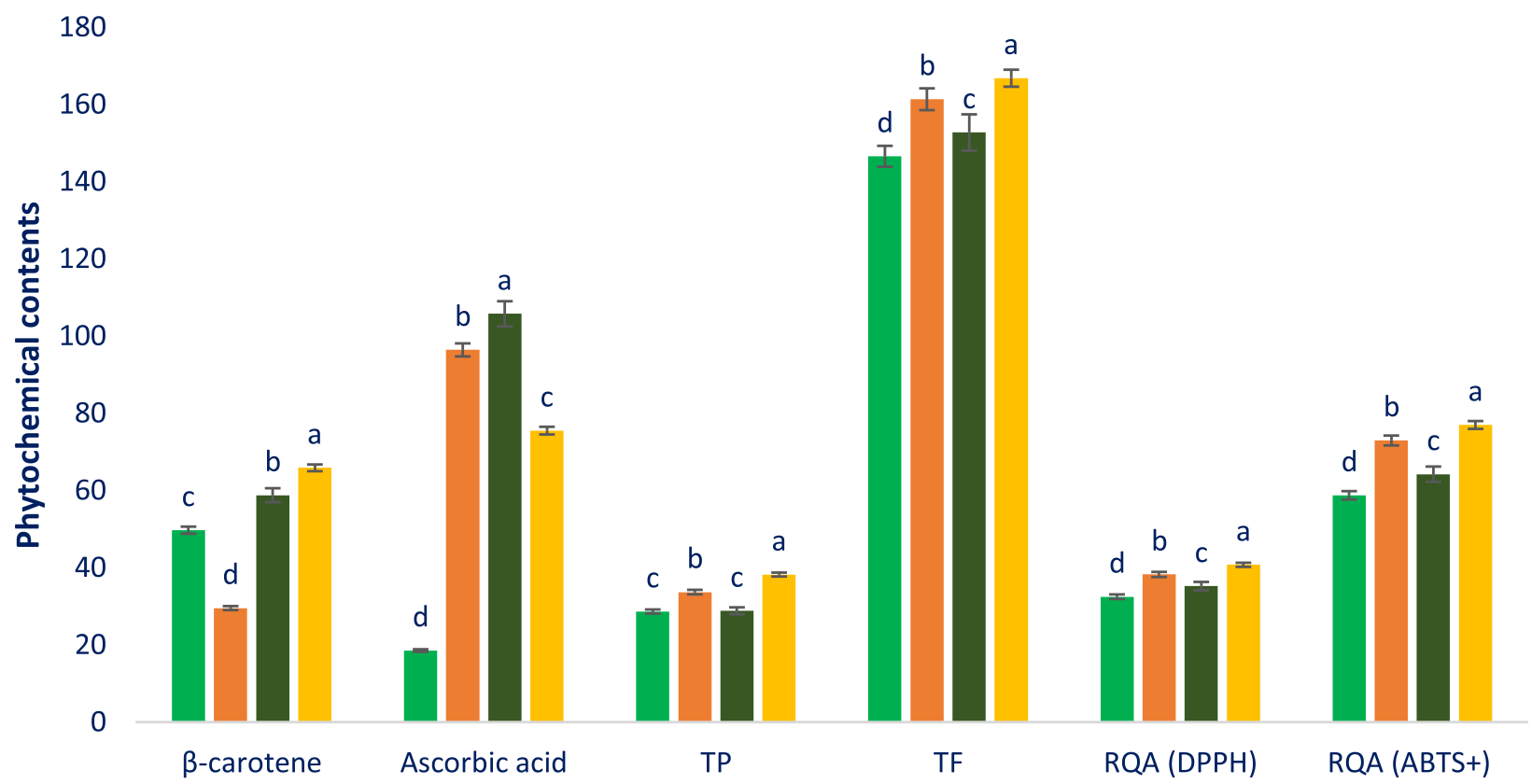

Fig. 4 Phytochemical contents and radical quenching ability in four selected drought-tolerant vegetable amaranth, $\beta$-carotene ( $\mathrm{mg} 100 \mathrm{~g}^{-1} \mathrm{FW}$ ), ascorbic acid (mg $100 \mathrm{~g}^{-1} \mathrm{FW}$ ), Gallic acid equivalent total polyphenols (TP, $\mu \mathrm{g} \mathrm{g}{ }^{-1} \mathrm{FW}$ ), rutin equivalent total flavonoids (TF, $\mu \mathrm{g} \mathrm{g} \mathrm{g}^{-1} \mathrm{DW}$ ), Trolox equivalent radical quenching ability (DPPH) $\left(\mu \mathrm{g} \mathrm{g}^{-1} \mathrm{DW}\right)$, Trolox equivalent radical quenching ability $\left(\mathrm{ABTS}^{+}\right)\left(\mu \mathrm{g} \mathrm{\textrm {g } ^ { - 1 }}\right.$ DW); different letters in the bar are differed significantly by Duncan Multiple Range Test $((P<0.01),(n=6)$

flavanols, flavones, and flavanones compounds of leaves of the selected amaranth. The four identified principal flavonoids groups showing the order: flavonols > flavanones $>$ flavones $>$ flavanols (Figs. 5 and 6). Across six flavonols, quercetin and rutin were quantified as the most prominent compounds followed by myricetin and isoquercetin in selected amaranth genotypes. Across the genotypes, AT15 demonstrated the maximum flavonols including the highest rutin and hyperoside. AT7 showed high total flavonols including the highest kaempferol, myricetin, isoquercetin, and quercetin. AT3 and AT11 contained low total flavonols including low kaempferol, rutin, hyperoside, myricetin, isoquercetin, and quercetin.

Kaempferol, rutin, hyperoside, myricetin, isoquercetin, and quercetin of selected amaranth genotypes varied from 4.78 to $7.82,8.54$ to $27.53,4.22$ to $5.66,7.38$ to $12.53,4.45$ to 9.34 , and 8.59 to $18.25 \mathrm{mg} \mathrm{kg}^{-1} \mathrm{FW}$, respectively (Fig. 5). AT7 demonstrated the maximum flavanols i. e., catechin followed by AT15. AT15 demonstrated the highest flavones i. e., apigenin, and

Table 2 Retention time (Rt), wavelengths of maximum absorption in the visible region $\left(\lambda_{\max }\right)$, mass spectral data and tentative identification of flavonols, flavanols, flavones, and flavanones in four selected drought-tolerant vegetable amaranth

\begin{tabular}{llllll}
\hline Peak no & $\begin{array}{l}\mathbf{R t} \\
(\mathbf{m i n})\end{array}$ & $\lambda_{\max }(\mathbf{n m})$ & $\begin{array}{l}\text { Molecular ion } \\
{[\mathbf{M}-\mathbf{H}]^{-}}\end{array}$ & $\begin{array}{l}\mathbf{M S}^{\mathbf{2}} \\
(\mathbf{m} / \mathbf{z})\end{array}$ & Identity of tentative compounds \\
\hline 1 & 4.62 & 370 & 626.2142 & 626.2587 & Myricetin-3-O-rutinoside \\
2 & 7.57 & 370 & 301.0487 & 301.0368 & 2-(3,4-dihydroxy phenyl)-3,5,7-trihydroxychromene-4-one \\
3 & 15.52 & 370 & 270.3524 & 270.3246 & 4',5,7-Trihydroxyflavone, 5,7-Dihydroxy-2-(4-hydroxyphenyl)-4-benzopyrone \\
4 & 17.88 & 370 & 593.5264 & 593.3372 & kaempferol-3-O-rutinoside \\
5 & 23.95 & 280 & 290.2341 & 290.2374 & (2R-3S)-2-(3,4-dihydroxyphenyl)-3,4-dihydro-2-chromene-3,5,7-triol \\
6 & 26.76 & 280 & 271.0785 & 271.1742 & Naringenin \\
7 & 54.38 & 360 & 463.3187 & 463.3421 & Quercetin-3-O-glucoside \\
8 & 53.32 & 360 & 463.4584 & 463.5246 & Quercetin-3-O-galactoside \\
9 & 53.35 & 360 & 609.3592 & 609.3623 & Quercetin-3-O-rutinoside \\
\hline
\end{tabular}




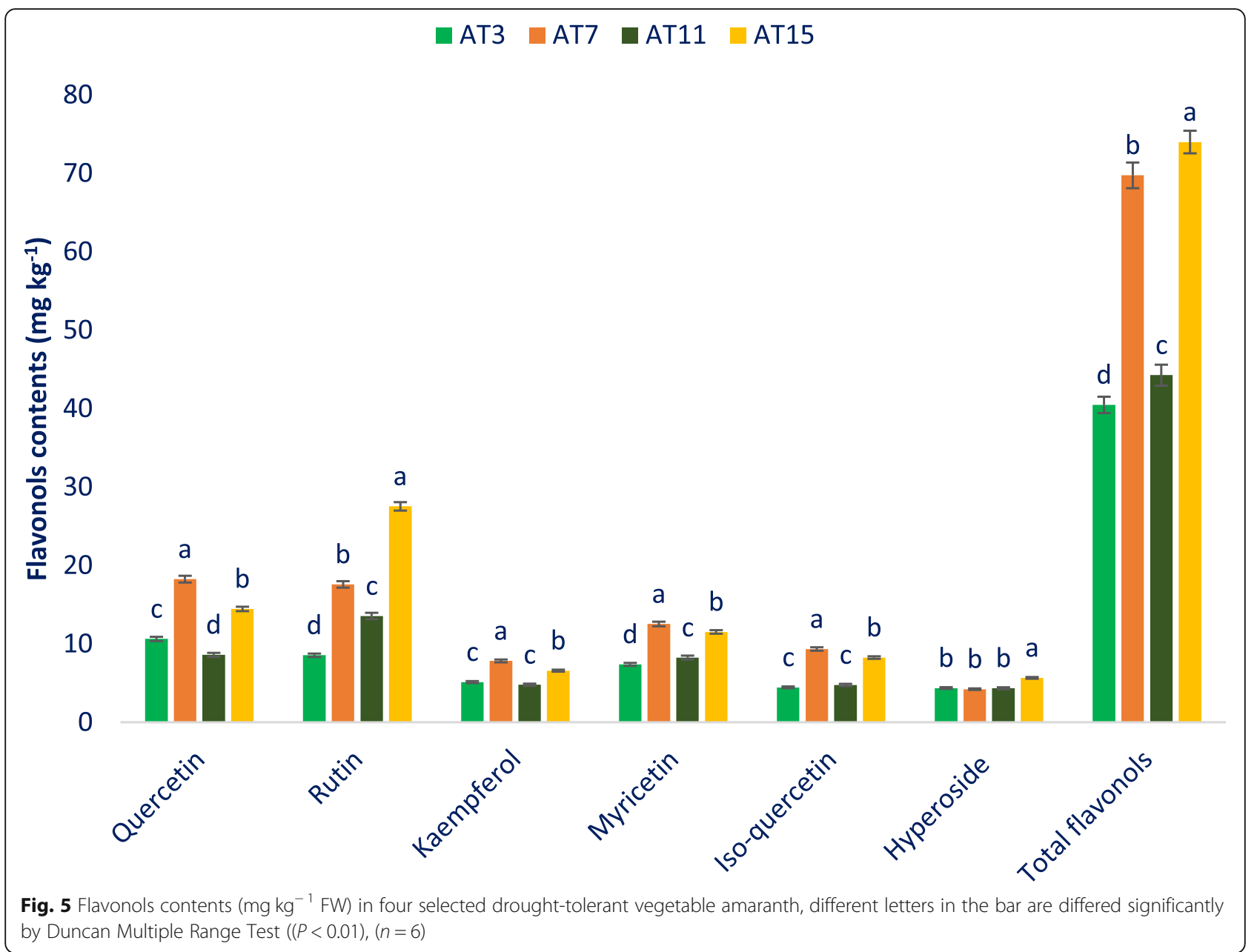

flavanones, like naringenin followed by AT7. (Fig. 6). In contrast, AT11 had the minimum flavanols i. e., catechin followed by AT3. AT3 showed the minimum flavones i. e., apigenin, and flavanones, like naringenin followed by AT11 (Fig. 6).

\section{The correlation studies}

The correlation of phytopigments, $\beta$-carotene, ascorbic acid, TF, TP, and radical quenching ability in $\mathrm{ABTS}^{+}$ and DPPH of the selected amaranth genotypes are put in Table 3. The correlation of phytopigments, $\beta$ carotene, ascorbic acid, TF, TP, and radical quenching ability in $\mathrm{ABTS}^{+}$and DPPH of the amaranth genotypes demonstrated interesting results. All phytopigments positively and significantly correlated among TF, TP, and radical quenching ability in $\mathrm{ABTS}^{+}$and $\mathrm{DPPH}$. Similarly, ascorbic acid demonstrated a positive and significant interrelationship with TF, TP, and radical quenching ability in $\mathrm{ABTS}^{+}$and $\mathrm{DPPH}$, while it exhibited insignificant negative associations among all phytopigments.
A significant positive association was exhibited among $\beta$-carotene, ascorbic acid, TF, TP, and radical quenching ability in $\mathrm{ABTS}^{+}$and DPPH. Phytopigments and Phytochemicals including $\beta$-carotene, ascorbic acid, TP, and TF showed significant associations with radical quenching ability in $\mathrm{ABTS}^{+}$and $\mathrm{DPPH}$.

\section{Discussion}

Nowadays, consumers and food researchers are fascinated by nutraceuticals and phytochemicals including vitamins, phytopigments, flavonoids, and polyphenols of plant origins, their antioxidant potentials, availability in diets, and activity of preventing fatal diseases viz., neurodegenerative, cancer, and cardiovascular diseases [54]. Phytopigments, vitamins including $\beta$-carotene and vitamin $C$, flavonoids, and polyphenol compounds from natural origins, such as vegetables and fruits serve as antioxidants and protect several diseases [55]. Antioxidants compounds reduce oxidative damage to the body through inhibition of the oxidizing chain reactions caused by free radicals [56]. 


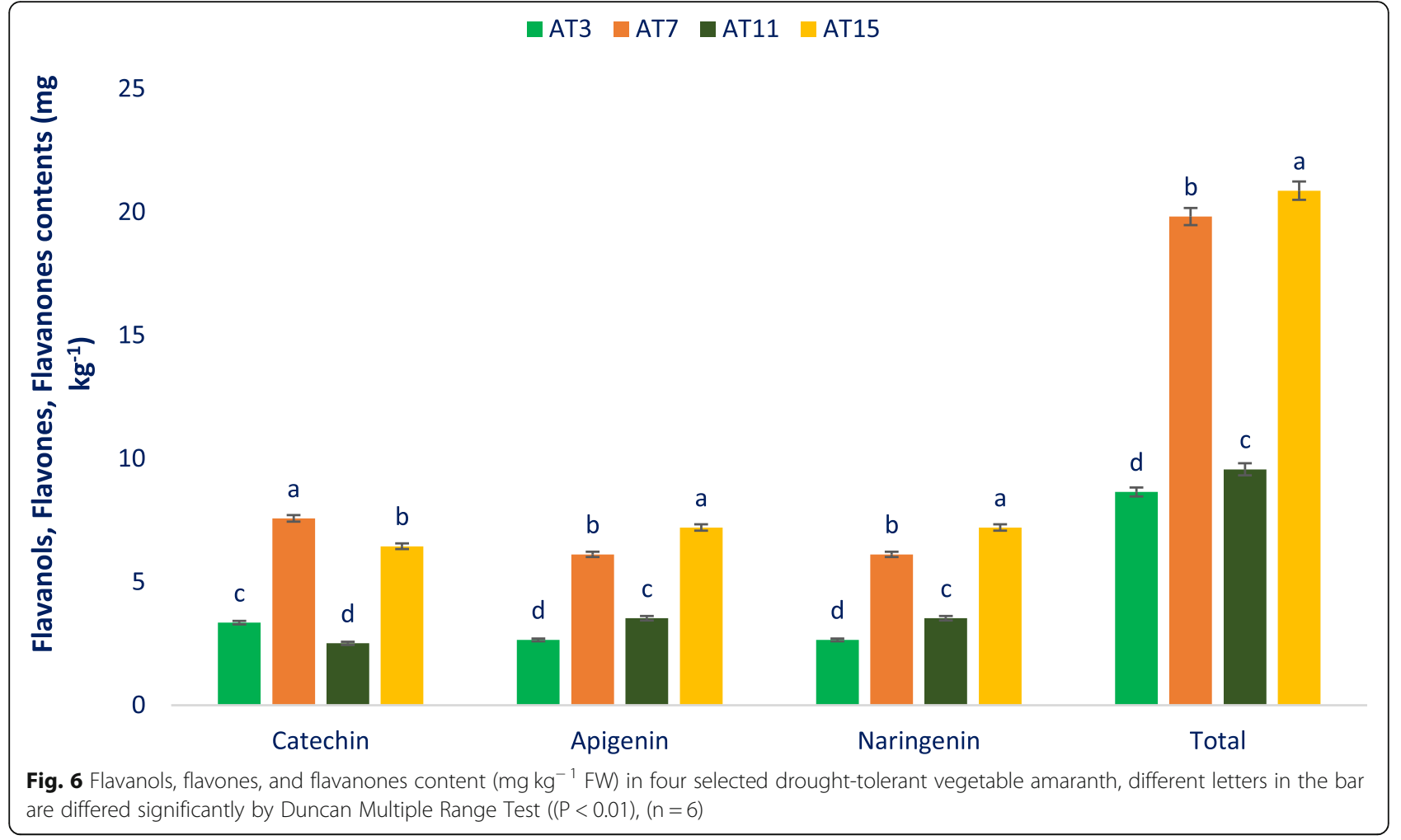

The ANOVA has shown that amaranth demonstrated huge variations across the traits studied. Huge variations across the traits studied were also noticed in A. hypochondriacus [42], rice [57-71], maize [72-74], and coconut $[75,76]$. Across four drought-tolerant vegetable amaranth, only AT7 showed low moisture content. As more leaf mass (dry) was obtained from lower moisture contents, accessions AT7 (18\% dry matter) had considerable biomass (dry). The maturity is directly interrelated to the leaf's moisture content. Literature has shown the corroborative results in sweet potato [77] and A. tricolor [21]. Leaves of selected amaranth demonstrated adequate protein content that significantly varied regarding accessions albeit variability was not prominent. Poor people and vegetarians of low-income countries mainly depend on vegetable amaranth for their protein source. The protein of amaranth was much pronounced as compared to A tricolor (1.26\%) of the previous study [2]. The lines exhibited low fat and might be consumed as a cholesterol-free food. The selected amaranth demonstrated no significant variability in fat content. Our results had conformity with the study of A. tricolor [21] and sweet potato [77]. The selected amaranth demonstrated significant variability in carbohydrates content regarding accessions. Digestible fiber significantly and predominantly varied regarding accessions. Digestible fiber remarkably contributed to the cure of constipation, increment of digestibility, and palatability [2]. Leaves of amaranth have abundant protein, moisture, carbohydrates, and digestible fiber. This study had conformity with our earlier study [21]. The moisture and protein contents observed in amaranth were pronounced than moisture and protein of red amaranth [78], green amaranth [79], weedy amaranth [80], stem amaranth [81], and A. blitum [82]. The carbohydrates content of AT7 were pronounced than the carbohydrates content of red amaranth [78], green amaranth [79], A. spinosus weedy amaranth [80], and A. blitum [82], while this line corroborated with carbohydrates content of stem amaranth [81]. The digestible fiber of the advance lines AT3 and AT7 were pronounced than the digestible fiber of red amaranth [78], green amaranth [79], stem amaranth [81], and A. blitum [82], while these lines corroborated with digestible fiber contents of weedy amaranth [80].

It revealed that we noted ample potassium $(6.68 \mathrm{mg}$ $\left.\mathrm{g}^{-1}\right)$ and magnesium (3.62 $\left.\mathrm{mg} \mathrm{g}^{-1}\right)$, and $\mathrm{Ca}\left(2.48 \mathrm{mg} \mathrm{g}^{-1}\right)$ in the amaranth genotypes (based on fresh weight). Ample magnesium, calcium, and potassium were noted in several species of amaranth [83]. Additionally, they noticed that amaranth's magnesium, calcium, and potassium were much prominent than black spider flower, nightshade, kale, and spinach. The magnesium, calcium, and potassium recorded in the selected amaranth were much pronounced than the magnesium, calcium, and potassium of amaranths [83] and fresh walnut [84]. The potassium of the lines was pronounced than the 


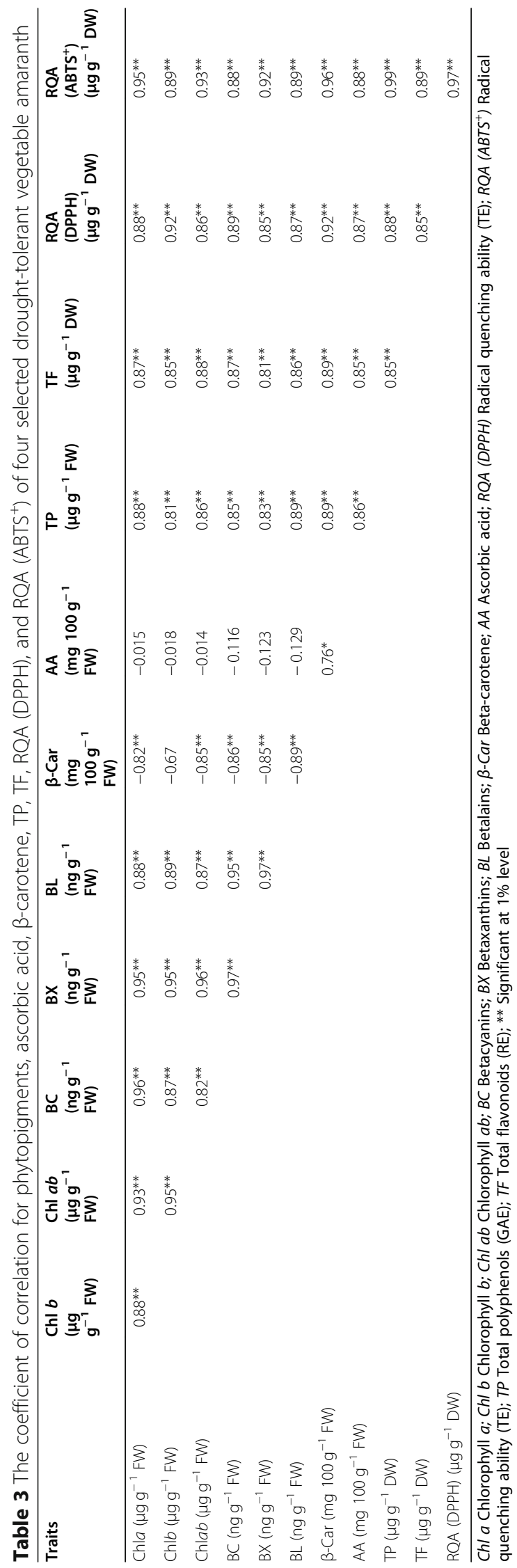


potassium of green amaranth [79], while potassium content obtained from these advance lines was lower than the potassium of weedy amaranth [80]. The calcium content observed in the genotypes were corroborative to green amaranth [79] and weedy amaranth [80]. The magnesium recorded in the advance lines was pronounced than green amaranth [79] and weedy amaranth [80]. The iron content demonstrated prominent variations regarding accessions. It has shown that significant variability was recorded in the manganese of the selected amaranth. The copper demonstrated no notable variability in the amaranth genotypes. The zinc of the selected amaranth differed significantly and markedly. The zinc and iron of the selected amaranth were more pronounced than cassava (leaf) [85] and beach pea [86]. It revealed from this investigation that ample iron $\left(17.26 \mu \mathrm{g} \mathrm{g}^{-1}\right)$, manganese $\left(10.54 \mu \mathrm{g} \mathrm{g}^{-1}\right)$, zinc $(12.25 \mu \mathrm{g}$ $\left.\mathrm{g}^{-1}\right)$, and notable copper $\left(2.18 \mu \mathrm{g} \mathrm{g}^{-1}\right)$ (based on fresh weight) were recorded in amaranth genotypes. Similarly, adequate iron, manganese, copper, and zinc were noticed in different amaranths [83]. They also noticed that manganese, iron, zinc, and copper in amaranth genotypes were pronounced than the flower of spider, kale, nightshade (black), and spinach. Our obtained manganese, zinc, iron, and copper content were much pronounced than the manganese, zinc, iron, and copper content of different amaranths [83]. The manganese and iron contents of all advance lines were much pronounced than green amaranth [79], while manganese and iron contents of AT15 were much pronounced than weedy amaranth [80]. Copper content observed in the lines was much pronounced than green amaranth [79], and A. spinosus weedy amaranth [80]. Zinc content observed in the advance line AT15 was much pronounced than green amaranth [79] and weedy amaranth [80].

The significant variability in chlorophyll $a$ was noted regarding the selected amaranth (305.85 to

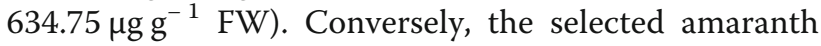
demonstrated minimum differences in chlorophyll $b$. Significant and outstanding variability in chlorophyll $a b$ were recorded in the amaranth genotypes. We observed adequate chlorophyll a $\left(634.75 \mathrm{\mu g} \mathrm{g}^{-1} \mathrm{FW}\right)$, chlorophyll $a b$ (901.13 $\left.\mathrm{\mu g} \mathrm{g}^{-1} \mathrm{FW}\right)$, and chlorophyll $b$ $\left(266.38 \mu \mathrm{g} \mathrm{g}^{-1} \mathrm{FW}\right)$ in the amaranth genotypes which was pronounced than the chlorophylls of green and red amaranth [87]. Chlorophyll $a$, chlorophyll $a b$, and chlorophyll $b$ in this study were much pronounced than chlorophyll $a$, chlorophyll $a b$, and chlorophyll $b$ of red amaranth [78], green amaranth [79], weedy amaranth [80], stem amaranth [81], and A. blitum [82]. The lines demonstrated betacyanins, betalains, and betaxanthins with significant variability regarding accessions. Likewise, betalains, carotenoids showed significant variability in the amaranth genotypes. Our study demonstrated prominent chlorophyll $a$ $\left(634.75 \mu \mathrm{g} \mathrm{g}^{-1} \quad\right.$ FW), chlorophyll $a b \quad\left(901.13 \mu \mathrm{g} \mathrm{g}^{-1}\right.$ FW), betacyanins (537.26 $\left.\mathrm{ng} \mathrm{g}^{-1} \mathrm{FW}\right)$, chlorophyll $b$ $\left(266.38 \mu \mathrm{g} \mathrm{g}^{-1} \mathrm{FW}\right)$, betaxanthins (588.75 $\left.\mathrm{ng} \mathrm{g}^{-1} \mathrm{FW}\right)$, betalains (1126.01 $\left.\mathrm{ng} \mathrm{g}^{-1} \mathrm{FW}\right)$ and carotenoids (82.85 $\left.\mathrm{mg} 100 \mathrm{~g}^{-1} \mathrm{FW}\right)$ in amaranth genotypes which were corroborated with chlorophyll $a$, betacyanins, chlorophyll $b$, betalains, chlorophyll $a b$, betaxanthins, and carotenoids of green and red amaranth [87]. Betacyanins, betalains, and betaxanthins in the amaranth were much pronounced than betacyanins, betalains, and betaxanthins of red amaranth [78], green amaranth [79] stem amaranth [81], and A. blitum [82]. Carotenoids were much pronounced than carotenoids of green amaranth [79] and corroborated with weedy amaranth [80] while carotenoids of studied amaranth were lower than red amaranth [78], stem amaranth [81], and A. blitum [82].

The significant variability was recorded in the $\beta$ carotene of the selected amaranth. The amaranth demonstrated significant variability in ascorbic acid. Marked and significant variability was obtained in gallic acid equivalent (GE) TP in amaranth genotypes. The lines demonstrated rutin equivalent (RE) TF with significant variability regarding accessions. The selected amaranth demonstrated significant variations in DPPH and $\mathrm{ABTS}^{+}$ radical quenching ability. The similarity in the trend of radical quenching ability in DPPH and $\mathrm{ABTS}^{+}$methods validated the quantification of two different methods of antioxidant capacities. The lines exhibited outstanding $\beta$-carotene and ascorbic acid (65.87 and $105.78 \mathrm{mg} 100$ $\left.\mathrm{g}^{-1} \mathrm{FW}\right)$ which was pronounced than red amaranth [2]. TP $\left(38.23 \mu \mathrm{g} \mathrm{g}^{-1} \mathrm{FW}\right)$, TF $\left(166.81 \mu \mathrm{g} \mathrm{g}^{-1} \mathrm{DW}\right)$, radical

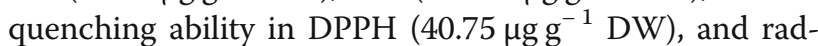
ical quenching ability in $\mathrm{ABTS}^{+}\left(76.98 \mu \mathrm{gg}^{-1} \mathrm{DW}\right)$ obtained in amaranth was pronounced than the contents of these compounds in green and red amaranth [51]. The $\beta$-carotene recorded in the advance lines was corroborative to weedy amaranth [80]. The ascorbic acid recorded in the line AT11 was pronounced as green amaranth [79], weedy amaranth [80], stem amaranth [81], and A. blitum [82], and corroborative to red amaranth [78]. The TP of amaranth was pronounced than green amaranth [79] and weedy amaranth [80]. The TF, radical quenching ability in DPPH and $\mathrm{ABTS}^{+}$recorded in the advance lines was pronounced than red amaranth [78], green amaranth [79], weedy amaranth [80], stem amaranth [81], and A. blitum [82]. The lines AT15 and AT7 had high phenolics, flavonoids, and antioxidants including considerable nutrients, phytopigments, and vitamins in comparison to AT3 and AT11. These two accessions might be exploited as HYB cultivars containing ample antioxidant profiles and suitable to extract juice as drinks. It revealed from the investigation that 
the selected amaranth contained ample source of nutritional values, antioxidant phytochemicals, and antioxidant activity that put forward a large possibility to feed the community deficit in minerals, antioxidants, and vitamins.

Nine flavonoids were detected in the genotypes together with six flavonols, like kaempferol, rutin, hyperoside, myricetin, isoquercetin, and quercetin, one flavanol i. e., catechin, one flavone i. e., apigenin, and one flavanone, such as naringenin. For the first time, we identified one flavonol such as myricetin, one flavanol i. e., catechin, one flavone i. e., apigenin, and one flavanone, like naringenin in the amaranth genotypes. In green and red amaranth, three flavonols such as isoquercetin, hyperoside, and rutin were previously reported [51, 87]. Three flavonols, like kaempferol, rutin, and quercetin were previously recorded in the flowers, leaf, sprouts, seed, and stalks of several amaranth species (A. cruentus, $A$. caudatus, and A. hypochondriacus) [88]. The $A$. cruentus seeds and sprouts contained three flavonoids namely, rutin, isovitexin, and vitexin [89]. The four identified principal flavonoids groups of amaranth showing the order: flavonols $>$ flavanones $>$ flavones $>$ flavanols. Across six flavonols, quercetin and rutin were quantified as the most prominent compounds followed by myricetin and isoquercetin in selected amaranth genotypes. Across the genotypes, AT15 exhibited the maximum flavonols including the highest rutin and hyperoside. AT7 showed high total flavonols including the highest kaempferol, quercetin, isoquercetin, and myricetin. AT3 and AT11 contained low total flavonols including low rutin, quercetin, isoquercetin, kaempferol, myricetin, and hyperoside. Hyperoside and quercetin of selected genotypes were pronounced than the hyperoside and quercetin content of red amaranth [51]. The edaphic and climatic situations, differences in cultivars, management practices, and geographic differential may be contributed a key role in achieving greater hyperoside and quercetin in the lines in comparison to red amaranth [51]. Pronounced variability was observed for kaempferol, rutin, hyperoside, myricetin, isoquercetin, and quercetin of the selected amaranth genotypes. AT7 demonstrated the maximum flavanols i. e., catechin followed by AT15. AT15 demonstrated the maximum flavones i. e., apigenin, and flavanones, like naringenin followed by AT7.

The correlation of phytopigments, $\beta$-carotene, ascorbic acid, TF, TP, and radical quenching ability in $\mathrm{ABTS}^{+}$ and DPPH of the selected genotypes demonstrated interesting results. All phytopigments positively and significantly correlated among TF, TP, and radical quenching ability in $\mathrm{ABTS}^{+}$and DPPH. It indicated that the increment in TF, TP, and radical quenching ability in $\mathrm{DPPH}$ and $\mathrm{ABTS}^{+}$were directly related to the increment of chlorophylls, betacyanins, betaxanthins, betalains, and carotenoids or vice versa. It meant all studied phytopigments had good radical quenching ability. Similarly, ascorbic acid demonstrated a positive and significant interrelationship with TF, TP, and radical quenching ability in $\mathrm{ABTS}^{+}$and $\mathrm{DPPH}$, while it exhibited negative and insignificant correlations across all phytopigments. The earlier work of amaranth also reported a related trend $[22,26]$. A positive and significant association was exhibited among $\beta$-carotene, ascorbic acid, TF, TP, and radical quenching ability in $\mathrm{ABTS}^{+}$and $\mathrm{DPPH}$. The significant positive interrelationship of $\beta$-carotene, ascorbic acid, TP, and TF and radical quenching ability in $\mathrm{ABTS}^{+}$ and DPPH signify that $\beta$-carotene, ascorbic acid, TP, and TF had a powerful activity of antioxidants. The capacity of antioxidants validation of amaranth through differential methods confirmed the significance in the associations between radical quenching ability in $\mathrm{ABTS}^{+}$ and DPPH. Studied phytopigments and phytochemicals including $\beta$-carotene, ascorbic acid, TP, and TF demonstrated powerful activity of antioxidants, as these showed the significant associations with radical quenching ability in $\mathrm{ABTS}^{+}$and DPPH. All studied phytopigments, $\beta$ carotene, ascorbic acid, TP, and TF played a vital role in the antioxidant potentiality of the amaranth lines as these compounds had a powerful activity of antioxidants.

\section{Conclusions}

The selected amaranth contained adequate nutraceuticals, phytopigments, phytochemicals including radical quenching ability. Across nine identified flavonoids, naringenin, apigenin, catechin, myricetin were newly reported in drought-tolerant vegetable amaranth. Based on this study, pharmacologists could investigate the suitability of these crops in medicinal drug discovery. Across the accessions, AT7 and AT15 had abundant phytochemicals and radical quenching ability including considerable nutraceuticals and phytopigments in comparison to the accessions AT3 and AT11. The accessions AT7 and AT15 might be directly utilized as nutraceuticals, phytopigments, phytochemicals enrich high yielding commercial cultivars. AT7 and AT15 could also be utilized to extract juice as a source of potential nutritional value, antioxidant phytopigments, $\beta$-carotene, antioxidants, flavonoids, phenolics, and ascorbic acid in the diet to accomplishing nutritional and antioxidant sufficiency in the globe. These lines might significantly contribute to the promotion of health benefits and feeding the community across the globe deficit in nutraceuticals and antioxidants. Identified flavonoid compounds in amaranth genotypes open the new route for details pharmacological study. 


\section{Abbreviations}

ANOVA: Analysis of variance; $\mathrm{ABTS}^{+}$: 2,2'-azino-bis-(3-ethylbenzothiazoline-6sulphonic acid); AAS: Atomic absorption spectrophotometry; AOAC: Association of Official Agricultural Chemists; AsA: Ascorbic acid; DPPH: 2,2-diphenyl-1-picrylhydrazyl; DHA: Dehydroascorbate; DMRT: Duncan's Multiple Range Test; DTT: Dithiothreitol; DW: Dry weight; FW: Fresh weight; FRAP: Ferric reducing antioxidant power; GAE: Gallic acid equivalent; HCl: Hydrochloric acid; HPLC-UV: High performance liquid chromatography-ultra violet; LC-MS-ESI: Liquid chromatography-mass spectroscopy-electrospray ionization; ORAC: Oxygen radical absorbance capacity; RCBD: Completely randomized block design; RE: Rutin equivalent; ROS: Reactive oxygen species; RQA: Radical quenching activity; SD: Standard deviation; TEAC: Trolox equivalent antioxidant capacity; TF: Total flavonoid content; TP: Total polyphenol content

\section{Acknowledgements}

None.

\section{Authors' contributions}

US conceptualized and conducted the experiments, analyzed the data, helped with the experimental design, and prepared and revised the manuscript. SO revised the manuscript and give valuable suggestions. All authors read and approved the final manuscript.

\section{Funding}

No funding was received.

\section{Availability of data and materials}

All data generated or analyzed during this study are included in this article and available from the corresponding author on reasonable request.

\section{Ethics approval and consent to participate} Not applicable.

\section{Consent for publication}

Not applicable.

\section{Competing interests}

The authors declare that they have no competing interests.

\section{Author details}

'Department of Genetics and Plant Breeding, Faculty of Agriculture, Bangabandhu Sheikh Mujibur Rahman Agricultural University, Gazipur-1706, Bangladesh. 'Laboratory of Field Science, Faculty of Applied Biological Sciences, Gifu University, Yanagido 1-1, Gifu, Japan.

Received: 9 September 2020 Accepted: 2 December 2020

Published online: 14 December 2020

\section{References}

1. Sarker U, Islam MT, Rabbani MG, Oba S. Genotypic variability for nutrient, antioxidant, yield and yield contributing traits in vegetable amaranth. Food Agri Environ. 2014;12:168-74

2. Sarker U, Islam MT, Rabbani MG, Oba S. Variability, heritability and genetic association in vegetable amaranth (Amaranthus tricolor). Span J Agric Res. 2015;13:1-8 https://doi.org/10.5424/sjar/2015132-6843.

3. Sarker U, Islam MT, Rabbani MG, Oba S. Genotype variability in composition of antioxidant vitamins and minerals in vegetable amaranth. Genetika. 2015; 47:85-96.

4. Sarker U, Islam MT, Rabbani MG, Oba S. Genetic variation and interrelationship among antioxidant, quality and agronomic traits in vegetable amaranth. Turk J Agric For. 2016;40:526-35.

5. Sarker U, Islam MT, Rabbani MG, Oba S. Genotypic diversity in vegetable amaranth for antioxidant, nutrient and agronomic traits. Indian J Genet PI Breed. 2017:77:173-6.

6. Shukla S, Bhargava A, Chatterjee A, Srivastava J, Singh N, Singh SP. Mineral profile and variability in vegetable amaranth (Amaranthus tricolor). Plant Foods Hum Nutri. 2006:61:23-8.

7. Chakrabarty T, Sarker U, Hasan M, Rahman MM. Variability in minera compositions, yield, and yield contributing traits of stem amaranth (Amaranthus lividus). Genetika. 2018;50:995-1010.
8. Sarker U, Islam MT, Rabbani MG, Oba S. Variability in total antioxidant capacity, antioxidant leaf pigments and foliage yield of vegetable amaranth. J Integrative Agric. 2018a;17:1145-53.

9. Sarker U, Islam MT, Rabbani MG, Oba S. Antioxidant leaf pigments and variability in vegetable amaranth. Genetika. 2018b;50:209-20.

10. Sarker U, Islam MT, Rabbani MG, Oba S. Phenotypic divergence in vegetable amaranth for total antioxidant capacity, antioxidant profile, dietary fiber, nutritional and agronomic traits. Acta Agric Scand Section B- Soil Plant Sci. 2018c;68:67-76.

11. Venskutonis PR, Kraujalis P. Nutritional components of amaranth seeds and vegetables: a review on composition, properties, and uses. Comp Rev Food Sci Food Saf. 2013;12:381-412.

12. Repo-Carrasco-Valencia R, Hellstrom JK, Pihlava JM, Mattila PH. Flavonoids and other phenolic compounds in Andean indigenous grains: quinoa (Chenopodium quinoa), kaniwa (Chenopodium pallidicaule) and kiwicha (Amaranthus caudatus). Food Chem. 2010;120:128-33.

13. Cai $Y$, Sun $M$, Corke $H$. Antioxidant activity of betalains from plants of the Amaranthaceae. J Agril Food Chem. 2003;51:2288-94.

14. Rajan S, Markose BL. Horticultural Science Series-6. In: Peter KMV, editor. Propagation of horticultural crops. New Delhi: New India Publishing Agency; 2007. p. 201-320.

15. Dusgupta N, De B. Antioxidant activity of some leafy vegetables of India: a comparative study. Food Chem. 2007:101:471-4.

16. Isabelle M, Lee BL, Lim MT, Koh WP, Huang D, Ong CN. Antioxidant activity and profiles of common fruits in Singapore. Food Chem. 2010;123:77-84.

17. Steffensen SK, Rinnan A, Mortensen AG, Laursen B, Troiani RM, Noellemeyer EJ, Janovska D, Dusek K, Delano-Frier J, Taberner A, Christophersen C, Inge S, Fomsgaard IS. Variations in the polyphenol content of seeds of field grown Amaranthus genotypes. Food Chem. 2011;129:131-8.

18. Vahdati K, Lotfi N, Kholdebarin B, Hasani D, Amiri R. Screening for drought tolerant genotypes of Persian walnuts (Juglans regia L.) during seed germination. HortSci. 2009:44:1815-9.

19. Sarker U, Oba S. Drought stress effects on growth, ROS markers, compatible solutes, phenolics, flavonoids, and antioxidant activity in A. tricolor. Appl Biochem Biotechnol. 2018;186:999-1016. https://doi.org/10.1007/s12010018-2784-5.

20. Vahdati K, Lotfi N. Abiotic stress tolerance in plants with emphasizing on drought and salinity stresses in walnut. In: Vahdati K, Leslie C, editors. Abiotic stress - plant responses and applications in agriculture. Rijeka: InTech; 2013. p. 307-65.

21. Sarker U, Oba S. Response of nutrients, minerals, antioxidant leaf pigments, vitamins, polyphenol, flavonoid and antioxidant activity in selected vegetable amaranth under four soil water content. Food Chem. 2018;252: 72-83.

22. Sarker U, Oba S. Drought stress enhances nutritional and bioactive compounds, phenolic acids and antioxidant capacity of Amaranthus leafy vegetable. BMC Plant Biol. 2018;18:258. https://doi.org/10.1186/s12870-018-1484-1.

23. Sarker U, Oba S. Catalase, superoxide dismutase, and ascorbate-glutathione cycle enzymes confer drought tolerance of Amaranthus tricolor. Sci Rep. 2018;8:16496. https://doi.org/10.1038/s41598-018-34944-0.

24. Sarker U, Oba S. Salinity stress enhances color parameters, bioactive leaf pigments, vitamins, polyphenols, flavonoids and antioxidant activity in selected Amaranthus leafy vegetables. J Sci Food Agric. 2019;99:2275-84. https://doi.org/10.1002/jsfa.9423.

25. Sarker U, Islam MT, Oba S. Salinity stress accelerates nutrients, dietary fiber, minerals, phytochemicals and antioxidant activity in Amaranthus tricolor leaves. PLoS One. 2018;13:0206388. https://doi.org/10.1371/journal.pone.0206388.

26. Sarker U, Oba S. Augmentation of leaf color parameters, pigments, vitamins, phenolic acids, flavonoids and antioxidant activity in selected Amaranthus tricolor under salinity stress. Sci Rep. 2018:8:12349. https://doi.org/10.1038/ s41598-018-30897-6.

27. Sarker $U$, Oba S. The response of salinity stress-induced A. tricolor to growth anatomy, physiology, non-enzymatic and enzymatic antioxidants. Front Plant Sci. 2020:11:559876. https://doi.org/10.3389/fpls.2020.559876.

28. Hanson P, Yang RY, Chang LC, Ledesma L, Ledesma D. Carotenoids, ascorbic acid, minerals, and total glucosinolates in choysum (Brassica rapa cv. parachinensis) and kailaan (B. oleraceae Alboglabra group) as affected by variety and wet and dry season production. J Food Comps Anal. 2011:24:950-62.

29. Hillova D, Takacsova M, Lichtnerova H. Stomatal response to water stress in herbaceous perennials. Plants Urban Areas Landscape. 2014. https://doi.org/ 10.15414/2014.9788055212623.52-56. 
30. Stagnari F, Angelica G, Mychele P. Water stress and crop plant: a sustainable approach. In: Ahmad P, editor. Drought stress effect on crop quality. West Sussex: Wiley Ltd.; 2016. p. 375-87.

31. Siracusa L, Gresta F, Sperlinga E, Ruberto G. Effect of sowing time and soil water content on grain yield and phenolic profile of four buckwheat (Fagopyrum esculentum Moench.) varieties in a Mediterranean environment. J Food Comps Anal. 2017;62:1-7.

32. Gharibi S, Tabatabaei BES, Saeidi G, Goli SAH. Effect of drought stress on total phenolic, lipid peroxidation, and antioxidant activity of Achillea species. Appl Biochem Biotechnol. 2016;178:796-809.

33. Lotfi N, Vahdati K, Kholdebarin B, Hassani D, Amiri R. Peroxidase, guaiacol peroxidase and ascorbate peroxidase activity accumulation in leaves and roots of walnut trees in response to drought stress. Acta Hortic. 2010;861:309-16.

34. Lotfi N, Soleimani A, Vahdati K, Çakmakçı R. Comprehensive biochemical insights into the seed germination of walnut under drought stress. Sci Hortic. 2019;250:329-43.

35. Lotfi N, Vahdati K, Kholdebarin B, Amiri R. Drought-induced accumulation of sugars and proline in radicle and plumule of tolerant walnut varieties during germination phase. Acta Hortic. 2010;861:289-96.

36. Lotfi N, Vahdati K, Kholdebarin B, Amiri R. Soluble sugars and proline accumulation play a role as effective indices for drought tolerant screening in Persian walnut (Juglans regia L.) during germination. Fruits. 2009;65:1-14.

37. Azooz MM, Ismail AM, Abou-Elhamd MF. Growth, lipid peroxidation, and antioxidant enzyme activities as a selection criterion for the salt tolerance of three maize cultivars grown under salinity stress. Intl J Agric Biol. 2009;11: 21-6.

38. Blokhina O, Virolainen E, Fagerstedt KV. Antioxidants, oxidative damage, and oxygen deprivation stress. Ann Bot. 2003;91:179-94.

39. Iwai K. Antidiabetic and antioxidant effects of polyphenols in brown alga Ecklonia stolonifera in genetically diabetic KK-ay mice. Plant Foods Hum Nutr. 2008;63:163-9.

40. Rashad MMI, Sarker U. Genetic variations in yield and yield contributing traits of green amaranth. Genetika. 2020;52:391-404.

41. AOAC (Association of Analytical Chemists). Official methods of analysis. 17th ed. Gaithersburg: AOAC International; 2000.

42. Sarker U, Oba S. Nutritional and bioactive constituents and scavenging capacity of radicals in Amaranthus hypochondriacus. Sci Rep. 2020;10:19962. https://doi.org/10.1038/s41598-020-71714-3.

43. Sarker U, Hossain MN, lqbal MA, Oba S. Bioactive components and radical scavenging activity in selected advance lines of salt-tolerant vegetable amaranth. Front Nutr. 2020;7:587257. https://doi.org/10.3389/fnut.2020.587257.

44. Lichtenthaler HK, Wellburn AR. Determinations of total carotenoids and chlorophylls $\mathrm{a}$ and $\mathrm{b}$ of leaf extracts in different solvents. Biochem Soc Trans. 1983;603:591-2.

45. Sarker U, Oba S. Leaf pigmentation, its profiles and radical scavenging activity in selected Amaranthus tricolor leafy vegetables. Sci Rep. 2020;10: 18617. https://doi.org/10.1038/s41598-020-66376-0.

46. Wyler H, Vincenti G, Mercier M, Sassu G, Dreiding AS. Zur Konstitutiondes Randenfarbstoffes Betanin. 2. (vorlaufige) Mitteilung. Helv Chim Acta. 1959; 42:1696-8. https://doi.org/10.1002/hlca.19590420532.

47. Sarker U, Oba S. Polyphenol and flavonoid profiles and radical scavenging activity in selected leafy vegetable Amaranthus gangeticus. BMC Plant Biol. 2020;20:499. https://doi.org/10.1186/s12870-020-02700-0.

48. Jensen A. Chlorophylls and carotenoids. In: Hellebust JA, Craigie JS, editors. Handbook of physiological methods and biochemical methods. Cambridge: Cambridge University Press; 1978. p. 5-70.

49. Sarker U, Oba S. Phenolic profiles and antioxidant actifvities in selected drought-tolerant leafy vegetable amaranth. Sci Rep. 2020;10:18287. https:// doi.org/10.1038/s41598-020-71727-y.

50. Sarker U, Oba S. Antioxidant constituents of three selected red and green color Amaranthus leafy vegetable. Sci Rep. 2019;9:18233. https://doi.org/10 1038/s41598-019-52033-8.

51. Khanam UKS, Oba S, Yanase E, Murakami Y. Phenolic acids, flavonoids and total antioxidant capacity of selected leafy vegetables. J Functional Foods. 2012:4:979-87

52. Hasan-Ud-Daula M, Sarker U. Variability, heritability, character association, and path coefficient analysis in advanced breeding lines of rice (Oryza sativa L.). Genetika. 2020;52:711-26 (Accepted).

53. Hasan MJ, Kulsum MU, Majumder RR, Sarker U. Genotypic variability for grain quality attributes in restorer lines of hybrid rice. Genetika. 2020;52 (Accepted).
54. Manach C, Scalbert A, Morand C, Remesy C, Jimenez L. Polyphenols: food sources and bioavailability. Am J Clin Nutri. 2004;79:727-47.

55. Thaipong K, Boonprakob U, Crosby K, Cisneros-Zevallos L, Byrne DH. Comparison of ABTS, DPPH, FRAP, and ORAC assays for estimating antioxidant activity from guava fruit extracts. J Food Compos Anal. 2006;19: 669-75.

56. Namiki M. Antioxidants/anti-mutagens in food. Crit Rev Food Sci Nutri. 1990; 29:273-300.

57. Ganapati RK, Rasul MG, Mian MAK, Sarker U. Genetic variability and character association of T-Aman rice (Oryza sativa L.). Intl J Plant Biol Res. 2014;2:1-4.

58. Ali MA, Sarker U, MAK M, Islam MA, Fatema-Tuj-Johora. Estimation of genetic divergence in boro rice (Oryza sativa L.). Intl J BioRes. 2014;16:28-36.

59. Karim D, Sarker U, Siddique MNA, Mian MAK, Hasnat MZ. Variability and genetic parameter analysis in aromatic Rice. Int J Sustain Crop Prod. 2007;2: $15-8$

60. Karim D, Sarker U, Siddique MNA, Mian MAK, Hasnat MZ. Phenotypic and genotypic correlation co-efficient of quantitative characters and character association of aromatic rice. J BioSci Agric Res. 2014;1:34-46.

61. Rai PK, Sarker U, Roy PC, Islam AKMS. Character Association in $F_{4}$ generation of rice (Oryza sativa L.). Bangladesh J PI Breed Genet. 2013;26:39-44.

62. Biswas PS, Sarker U, Bhuiyan MAR, Khatun S. Genetic divergence in cold tolerant irrigated rice (Oryza sativa L.). Agriculturists. 2006;4:15-20.

63. Sarker U, Mian MAK. Genetic variations and correlations between floral traits in rice. Bangladesh J Agril Res. 2004;29:553-8.

64. Sarker U, Mian MAK. Genetic variability, character association and path analysis for yield and its components in rice. J Asiat Soc Bangladesh Sci. 2003;29:47-54.

65. Sarker U, Biswas PS, Prasad B, Mian MAK. Correlated response, relative selection efficiency and path analysis in cold tolerant rice. Bangladesh J PI Breed Genet. 2001:14:33-6.

66. Nath JK, Sarker U, Mian MAK, Hossain T. Genetic divergence in T. Aman rice. Ann Bangladesh Agric. 2008;12:51-60.

67. Hasan MR, Sarker U, Mian MAK, Hossain T, Mahmud MNH. Genetic variation in micronutrient dense rice and its implication in breeding for higher yield. Eco-friendly Agril J. 2012:5:175-82.

68. Hasan MR, Sarker U, Islam MR, Mahmud MNH. Genetic diversity in micronutrient dense rice and its implication in breeding program. Ecofriendly Agril J. 2012:5:183-5.

69. Rahman MH, Sarker U, Main MAK. Assessment of variability of floral and yield traits; II maintainer lines of rice. Ann Bangladesh Agric. 2007;11:95-102.

70. Rahman MH, Sarker U, Main MAK. Assessment of variability of floral and yield traits; I restorer lines of rice. Ann Bangladesh Agric. 2007;11:87-94.

71. Siddique MNA, Sarker U, Mian MAK. Genetic diversity in restorer line of rice In: proceedings of the international conference on plant breeding and seed for food security. In: Bhuiyan MSR, Rahman L, editors. Plant Breeding and Genetics Society of Bangladesh; 2009. p. 137-42.

72. Biswas A, Sarker U, Banik BR, Rohman MM, Mian MAK. Genetic divergence study in salinity stress tolerance maize (Zea mays L.). Bangladesh J Agril Res. 2014;39:621-30.

73. Azam MG, Sarker U, Mahmud JA, Maniruzzam M, Banik BR. Genetic variability of yield and its contributing characters of CIMMYT maize inbreds in stress condition. Bangladesh J Agril Res. 2014;39:419-26.

74. Azam MG, Sarker U, Mian MAK, Banik BR, Talukder MZA. Genetic divergence on quantitative characters of exotic maize inbreds (Zea mays L.). Bangladesh J PI Breed Genet. 2013;26:09-14.

75. Talukder MZA, Sarker U, Harun-Or-Rashid MMAK, Zakaria M. Genetic diversity of coconut (Cocos nucifera L.) in Barisal region. Ann Bangladesh Agric. 2015;19:13-21.

76. Talukder MZA, Sarker U, Khan ABMMM, Moniruzzaman M, Zaman MM. Genetic variability and correlation coefficient of coconut (Cocos nucifera L.) in Barisal region. Intl J BioRes. 2011;11:15-21.

77. Sun H, Mu T, Xi L, Zhang M, Chen J. Sweet potato (Ipomoea batatas L.) leaves as nutritional and functional foods. Food Chem. 2014;156:380-9.

78. Sarker U, Oba S. Protein, dietary fiber, minerals, antioxidant pigments and phytochemicals, and antioxidant activity in selected red morph Amaranthus leafy vegetable. PLoS One. 2019;14:0222517. https://doi.org/10.1371/journal. pone.0222517

79. Sarker U, Hossain MM, Oba S. Nutritional and antioxidant components and antioxidant capacity in green morph Amaranthus leafy vegetable. Sci Rep. 2020;10:1336. https://doi.org/10.1038/s41598-020-57687-3.

80. Sarker U, Oba S. Nutraceuticals, antioxidant pigments, and phytochemicals in the leaves of Amaranthus spinosus and Amaranthus viridis weedy species. Sci Rep. 2019;9:20413. https://doi.org/10.1038/s41598-019-50977-5. 
81. Sarker U, Oba S, Daramy MA. Nutrients, minerals, antioxidant pigments and phytochemicals, and antioxidant capacity of the leaves of stem amaranth. Sci Rep. 2020;10:3892. https://doi.org/10.1038/s41598-020-60252-7.

82. Sarker U, Oba S. Nutrients, minerals, pigments, phytochemical, and radical scavenging activity in Amaranthus blitum leafy vegetable. Sci Rep. 2020;10: 3868. https://doi.org/10.1038/s41598-020-59848-w.

83. Jimenez-Aguilar DM, Grusak MA. Minerals, vitamin C, phenolics, flavonoids and antioxidant activity of Amaranthus leafy vegetables. J Food Compos Anal. 2017:58:33-9.

84. Chatrabnous N, Yazdani N, Vahdati K. Determination of nutritional value and oxidative stability of fresh walnut. J Nuts. 2018;9:11-20.

85. Madruga MS, Camara FS. The chemical composition of "Multimistura" as a food supplement. Food Chem. 2000;68:41-4.

86. Shahidi F, Chavan UD, Bal AK, McKenzie DB. Chemical composition of beach pea (Lathyrus maritimus L.) plant parts. Food Chem. 1999:64:39-44

87. Khanam UKS, Oba S. Bioactive substances in leaves of two amaranth species, Amaranthus tricolor and A. hypochondriacus. Canadian J PI Sci. 2013; 93:47-58.

88. Li H, Deng Z, Liu R, Zhu H, Draves J, Marcone M, Sun Y, Tsao R. Characterization of phenolics, betacyanins and antioxidant activities of the seed, leaf, sprout, flower and stalk extracts of three Amaranthus species. J Food Compos Anal. 2015;37:75-81.

89. Pasko P, Sajewicz M, Gorinstein S, Zachwieja Z. Analysis of selected phenolic acids and flavonoids in Amaranthus cruentus and Chenopodium quinoa seeds and sprouts by HPLC. Acta Chromatogr. 2008;20:661-72.

\section{Publisher's Note}

Springer Nature remains neutral with regard to jurisdictional claims in published maps and institutional affiliations.

Ready to submit your research? Choose BMC and benefit from:

- fast, convenient online submission

- thorough peer review by experienced researchers in your field

- rapid publication on acceptance

- support for research data, including large and complex data types

- gold Open Access which fosters wider collaboration and increased citations

- maximum visibility for your research: over $100 \mathrm{M}$ website views per year

At $\mathrm{BMC}$, research is always in progress.

Learn more biomedcentral.com/submissions 